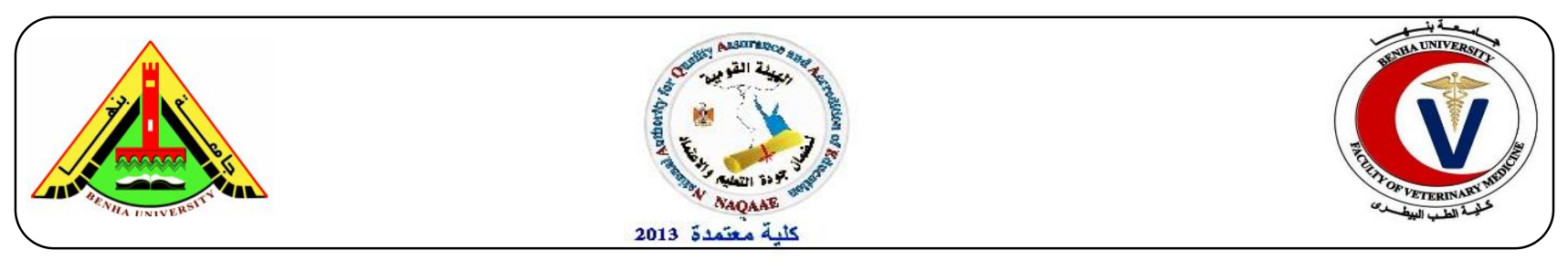

\title{
Screening for Antimicrobial Resistance in some Pathogens isolated from Cold Smoked Fish Marketed in Menofiya Government
}

\author{
Hassanen, F.S. ${ }^{1}$, Sabike, I.I. ${ }^{1}$, Haikel , G. I. ${ }^{2}$ and Elged, E. $A^{\mathbf{3}}$. \\ ${ }^{1}$ Dep. Of Food hygiene, Fac. Vet. Med., Benha University. \\ ${ }^{2}$ Animal Health Research Institute Tanta lab. \\ ${ }^{3}$ Veterinarian. \\ Correspondence: mrawan.nasr.vet@gmail.com.
}

\section{A B S T R A C T}

The objective of this study was to demonstrate the prevalence and antibiotic resistance characteristics of Salmonella species, E. coli and listeria species were isolated conventionally from ninety cold smoked fish (Herring, Clupea), from souk and markets in Menofiya province, Egypt. The Coliform Count was significantly higher $(\mathrm{P}<0.05)$ in souk than markets with mean counts of $4.07 \pm 0.23$ and 3.13 $\pm 0.40 \mathrm{Log}$ CFU/gm. The overall prevalence of Salmonella sp. was 2.2\% (2/90), and all of them were detected from a souk samples, while E. coli isolates were $13.3 \%$ (12/90), but, Listeria spp. failed to be detected in tested samples. Conventionally, Salmonella spp. were phenotypically resistant to three, Cefozon, E-Moxclave, and Clindamycin, of 8 commonly used antibiotics in Egypt. Whilst, E.coli strain showed resistance to Cefozon, Gentamicin, Cefotaxime, Doxycycline, E-Moxclave, and Clindamycin. A multi-resistance was observed in one Salmonella strain, and in $83.3 \%(5 / 6)$ of tested E. coli strain. Further, the molecular results showed that all isolated salmonella $(n=2)$ and E. coli $(n=6)$ strains contained the beta-lactam resistance genes,

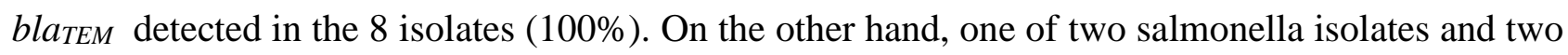
of six E. coli strain were positive for erm(B) (erythromycin ribosome methylase) genes. This study may be the first report on antimicrobial resistant Salmonella species, Escherichia coli and listeria species in cold smoked fish (Herring, Clupea) marketed in Egypt.

Key words: Smoked Fish, Escherichia Coli, Salmonella, Listeria, Antimicrobial Resistance, Antibiotic Resistance Gene.

(http://www.bvmj.bu.edu.eg)

(BVMJ-35(2): 269-283, 2018)

\section{INTRODUCTION}

Fish is a vital source of nutrients to humans due to its proteinaceous nature, high content of unsaturated fatty acids and low contents of carbohydrates. Egypt is considered one of the ten major producers of fish from aquaculture, produced 236,992 tonnes in 2014 (FAO 2016). Smoked fish is one of the processed category of seafood, smoking mainly aimed to impart attractive appearance, flavor, and a longer shelf-life. Though, smoking process has some antimicrobial action but unhygienic food handling and storage procedures possible lead to the contamination with and the growth 
foodborne pathogens (Anderson et al. 2004; Firestone et al. 2007). Fish was classified as the most commonly implicated food category in foodborne outbreaks, caused 34 of 194 (18\%) foodborne outbreaks, in the United States (CDC 2017), For decades, Salmonella sp., E. coli, and Listeria monocytogenes have been associated with paramount food-borne illness and deaths each year, with immeasurable economic losses (Borch and Arinder 2002).In both developed and developing countries, Salmonellosis is considered an important foodborne disease which recurrently cause a major and unacceptable threat to human public health (EFSA (European Food Safety Authority) 2010).Another zoonotic pathogen is Listeria monocytogenes which results in a serious human illness called listeriosis (Donovan 2015). Severe clinical outcomes commonly resulted from listeriosis. Smoked fish that doesn't need further heat treatment, ready-toeat foods, is one the major source for listeriosis outbreaks (Møretrø et al. 2017; Tham et al. 2000). The unrationalized heavy use of antimicrobial agents in aquaculture for prevention and control of fish diseases resulted in the increased emergence of antibiotic resistant pathogens. The increase of these resistant strains can significantly impact human health, besides its adverse effects on the environment and the therapy of fish diseases. Data on antimicrobial resistance characterization of Salmonella sp., E. coli and Listeria $\mathrm{sp}$. isolated from smoked fish is very little, comparable to food of animal origin (Ryu et al. 2012).Smoked fish are generally eaten in many countries, of them Egypt. Thus, smoked fish deserve attention because their contamination by antimicrobial resistant foodborne pathogens such as Salmonella species, E.coli and Listeria monocytogenes can pose a fatal human diseases or hazard. Accordingly, it is necessary to estimate the bacteriological quality along with the previously mentioned pathogenic bacteria in smoked Herring, Clupea, sold in souk and markets, in Menofiya province, Egypt.

\section{MATERIALS AND METHODS}

2.1. Collection of samples:

A total of 90 randum herring fish samples whole fish of naturally-produced herring (wooden box smoked fish), were randomly and periodically collected about from 60 souk Herring and 30 from supermarkets in Berket El Sabi in Monefia, Egypt, then packaged and marked individually in polyethylene bags to avoid transport of microbes from one to another . These collected samples were transferred to the laboratory under complete aseptic condition without undue delay to be examination bacteriologically and determination antimicrobial resistance genes by PCR.

\subsection{Preparation of samples:}

Aseptically, twice 25 grams were taken of each smoked fish sample, and then, separately homogenized in $225 \mathrm{ml}$ of $0.1 \%$ sterile buffered peptone water for $5 \mathrm{~min}$ at room temperature. One of the homogenate used for detection of Salmonella species, while the second homogenate was used for other bacteriological analysis.

\subsection{Bacteriological Analysis:}

Standard pour plate method of Sutton (2011) and Egyptian standards No. 5647/2006 which follow (Iso: 4832 /2005) (ISO 2005) were used for determining total coliform count. Briefly, a serial 10-fold dilution of sample were prepared using sterile normal saline, then dilutions of each sample were inoculated in duplicate sterile petri dishes followed by pouring Violet red bile agar (VRBG) agar. The inoculated plates were then incubated at $37^{\circ} \mathrm{C}$ for $24 \mathrm{~h}$ before colonies were counted. 
2.4. Conventional isolation of E. coli strains:

E.coli strain were isolated using the method of the Bacteriological Analytical Manual (USFDA, 1998). One $\mathrm{ml}$ of homogenized meat sample inoculated into MacConkey broth for enrichment of the $\mathrm{E}$. coli strains, and then incubated at $37{ }^{\circ} \mathrm{C}$ for 18 to $24 \mathrm{~h}$. The enriched cultures were streaked onto eosin methylene blue (EMB) agar in two plates and incubated at $37{ }^{\circ} \mathrm{C}$ for 24 h. Presumptive E. coli colonies on EMB plates, which were round and had a metallicgreen color with a dark or purple center, were further confirmed by inoculating the colonies EMB plates and incubated at $44{ }^{\circ} \mathrm{C}$ for $24 \mathrm{~h}$. Then presumptive E. coli colonies were picked up and kept in Semi-solid nutrient agar for biochemical and serological identification.

2.5. Conventional isolation of Salmonella spp.:

According to ISO 6579:2002 protocol (International Organization for Standardization(ISO) 2002), the homogenate specified for isolation of salmonella was incubated at $37^{\circ} \mathrm{C}$ for $22 \mathrm{~h}$ for preenrichment. After resuscitation, $0.1 \mathrm{~mL}$ was inoculated into $10 \mathrm{ml}$ Rappaport-Vassiliadis medium and incubated at $42^{\circ} \mathrm{C}$ for $24 \mathrm{~h}$. After enrichment, a loopful of each enriched sample was streaked onto xylose lysine desoxycholate agar and incubated at $37^{\circ} \mathrm{C}$ for $24 \mathrm{~h}$.

\subsection{Conventional isolation of Listeria spp.:}

Fish samples were tested for Listeria spp. using ISO Methodology No. 11290-1: 1996 recommended by Egyptian standards (ES)(ES 2006). To clarify, $10 \mathrm{~g}$ of each fish sample (flesh and skin) were homogenized in $90 \mathrm{ml}$ of half Fraser broth and then incubated at $30{ }^{\circ} \mathrm{C}$ for $24 \mathrm{~h}$. concurrently, a loopful were of homogenate was streaked onto Oxford agar and Listeria Identification Agar Base
(PALCAM) agar and incubated at $30^{\circ} \mathrm{C}$, then colonies examined after $24 \mathrm{~h}$ and $48 \mathrm{~h}$. An aliquot $(0.1 \mathrm{ml})$ was transferred to $10 \mathrm{ml}$ Fraser broth which incubated at $30{ }^{\circ} \mathrm{C}$ for $48 \mathrm{~h}$ then a loopful was streaked onto Oxford agar and PALCAM and the colonies were examined after $24 \mathrm{~h}$ and $48 \mathrm{~h}\left(30{ }^{\circ} \mathrm{C}\right)$. morphological, physiological and biochemical tests were carried out on presumptive colonies to Confirm the presence of $L$. monocytogenes (Gnanou Besse et al. 2016; Scotter et al. 2001).

\subsection{Antibiotic susceptibility tests:}

Eight isolates of salmonella $(\mathrm{n}=2)$ and E. coli (n=6) were sent to laboratory of Animal health research institute of Dokki, Giza, Egypt for conducting Antibiotic susceptibility tests. Of the $6 \mathrm{E}$. coli, one was from retail sampled herring and the other 5 were from souk. The standard procedure of the Clinical and Laboratory Standards Institute (CLSI) for disc diffusion techniques on Mueller Hinton agar were followed using the following commonly used antibiotic discs in Egyptian clinics; Cefozon (CFP), Gentamicin (CN), Ciprocin (CIP), Cefotaxime (CTX), Norfloxacin (NOR), Doxycycline (DO), E-Moxclave (AMC), and clindamycin (DA). (NCCLS, 2004) were strictly followed throughout the testing procedure.

2.8. Confirmation of pathogens and antibiotic resistance genes:

PCR was used to confirm isolated strain, whether they are Salmonella and E. coli or not and screen for two antibiotic resistance genes (ARGs) in the eight isolates of salmonella $(n=2)$ and E. coli $(n=6)$, which previously tested for phenotypic resistance to many antimicrobial agents. The occurrence of genes associated with ß-lactams (blaTEM), and macrolide (ermB) were detected by PCR assay. Extraction of Salmonella and E. coli 
DNA for PCR was carried out using by QIAamp DNA Mini kit (Qiagen Inc., USA). The PCR reaction mixture was prepared as recommended by EmeraldAmp® GT PCR Master Mix (TAKARA BIO INC, Tokyo, Japan) with little modification. Briefly, a final volume of $25 \mu \mathrm{l}$ was targeted, which contained $12.5 \mu \mathrm{l}$ of Emerald Amp GT PCR mastermix (2x premix), $1 \mu$ of each primer (Forward and Reverse primers), $6 \mu \mathrm{l}$ of Template DNA and $4.5 \mu 1$ (PCR grade Sterile distilled water). The PCR amplification for detecting blaTEM and ermB was conducted separately in Biometra T3 Thermal cycler (Biometra) under the following conditions: initial denaturation at $94{ }^{\circ} \mathrm{C}$ for $5 \mathrm{~min}$, followed by Secondary denaturation at $94{ }^{\circ} \mathrm{C}$ for $30 \mathrm{~s}$, annealing at $54{ }^{\circ} \mathrm{C}$ for $40 \mathrm{~s}$, and extension at $72{ }^{\circ} \mathrm{C}$ for 45 s for 35 cycles and then final cycle of amplification at $72{ }^{\circ} \mathrm{C}$ for $10 \mathrm{~min}$. similar cycling steps were assigned for the amplification of ermB except the annealing was at $45{ }^{\circ} \mathrm{C}$ for $40 \mathrm{~s}$. Oligonucleotide primer used for detection of salmonella and Escherichia coli B-lactams (blaTEM) resistance gene was TEM-C, ATCAGCAATAAACCAGC; and TEM-H, CCCCGAAGAACGTTTTC (Colom et al. 2003; Mabilat and Courvalin 1990). While macrolide resistance gene was ermB-F, GAAAAAGTACTCAACCAAATA; and ermB-R, AATTTAAGTACCGTTACT (Nguyen et al. 2009).

\section{RESULTS}

The Coliform Count of Souk cold smoked Herring and retail smoked herring were counted and compared as shown in table (1, 2). The statistical analysis of results (Table 2) showed that the mean coliform count of a Souk cold smoked Herring (4.07 0.23 Log CFU/gm) was significantly $(\mathrm{P}<0.05)$ higher than retail smoked Herring $(3.13 \pm 0.40 \mathrm{Log}$ CFU/gm). Of the 60 souk cold smoked Herrings, $13.3 \%$ (8/60) samples were totally negative for the occurrence of Coliform, with a maximum coliform count of $6.78 \mathrm{Log}$ CFU/gm. Besides, 30\% (9/30) of retail cold smoked Herrings were free of Coliform, with a maximum Coliform count of $6.68 \mathrm{Log}$ CFU/gm. The overall prevalence of Salmonella spp. currently isolated from cold smoked herring marketed in Egypt was 2.2\% (2/90). The two Salmonella spp. were only detected smoked Herring from Souk samples, while no Salmonella spp. was detected in cold smoked Herring sold in tested Egyptian retails (Tables 3). The overall prevalence of Escherichia coli in collected cold smoked herrings was $13.3 \%$. To illustrate, the incidence of Escherichia coli in the examined souk samples were $15 \%$ (9/60), while the incidence in retail samples was $10 \%(3 / 30)$ (Tables 3). All examined cold smoked herrings from souk and retail were negative for the presence of Listeria sp.

The two isolated Salmonella strains (100\%) showed resistance to E-Moxclave, and clindamycin, while one Salmonella strains additionally showed resistance to Cefozon $(50 \%)$. In contrast both strains were susceptible to Gentamicin (100\%), Ciprocin (100\%), Cefotaxime (100\%), Norfloxacin (100\%), Doxycycline (100\%). Similarly, Yan et al. (2010) reported that all 20 Salmonella strains isolated from seafood were susceptible Norfloxacin, but none of the strains were resistant to Amoxicillin-clavulanate (as EMoxclave) and Cefozon, while 5\%, 5\% and $10 \%$ were resistant to Gentamicin to Ciprofloxacin (Ciprocin) and Tetracycline (Doxycycline), respectively. All isolated E. coli strains were resistant to one or more antibiotics. The multi-resistance was observed in $83.3 \%(5 / 6)$ of tested E. coli strains. Of them, two isolates were resistant to 5 tested antibiotics and the other $2 \mathrm{E}$. coli strains were resistant to 4 tested antibiotics. Further, a $100 \%$ of isolated E. coli strains were resistant E-Moxclave, and clindamycin, while $83.3 \%$ (5/6) showed resistance to Cefozon and 
Cefotaxime. Also, 16.7\% (1/6) of E. coli was resistant to Gentamicin (Aminoglycosides) and to Doxycycline. However, all isolated E. coli $(100 \%)$ were susceptible to Norfloxacin. In the current study, the result showed that all isolated salmonella $(n=2)$ and E. coli $(n=6)$ strains contained the beta-lactam resistance genes, blaTEM detected in the 8 isolates $(100 \%)$.

Table (1) Statistical analysis of Coliforms Counts (Log CFU/g) of cold smoked Herring collected from Souk and super markets:

\begin{tabular}{|c|c|c|c|c|}
\hline Product & $\begin{array}{l}\text { Incidence } \\
\%\end{array}$ & $\begin{array}{l}\text { Minimum } \\
\text { (Log CFU/g) }\end{array}$ & $\begin{array}{l}\text { Maximum } \\
\text { (Log CFU/g) }\end{array}$ & $\begin{array}{l}\text { Mean } \pm \text { SE } \\
(\mathrm{Log} / \mathrm{CFU} / \mathrm{g})\end{array}$ \\
\hline
\end{tabular}

\begin{tabular}{|c|c|c|c|c|c|}
\hline $\begin{array}{l}\text { Souk } \\
(n=60)\end{array}$ & herring & $86.7 \%(52)$ & 0.954 & 6.78 & $4.07 \pm 0.23$ \\
\hline $\begin{array}{l}\text { Retail } \\
(n=30)\end{array}$ & herring & $70 \%(21)$ & 0.477 & 6.68 & $3.13 \pm 0.40$ \\
\hline
\end{tabular}

Figure (1) Mean coliform counts of cold smoked herring collected from Souk and supermarkets. 
Table (2) results of One-Way ANOVA for coliforms counts collected from cold smoked herring in Souk and supermarkets:

\begin{tabular}{llllll}
\hline Source & SS & DF & MS & F value & $p$-value \\
$\begin{array}{l}\text { Between } \\
\text { treatments }\end{array}$ & 17.7284 & 1 & 17.7284 & 4.76541 & 0.031699 \\
$\begin{array}{l}\text { Within } \\
\text { treatments }\end{array}$ & 327.3804 & 88 & 3.7202 & \\
Total & 345.1089 & 89 & & \\
\hline
\end{tabular}

Table (3): Comparison of incidence rates of Salmonella, Escherichia coli and Listeria strains isolated from souk and supermarkets Herring samples:

\begin{tabular}{lll}
\hline Targeted pathogens & Souk herring & Retail herring \\
Salmonella-positive $(n=2)$ & 2 & 0 \\
Escherichia coli-positive $(n=12)$ & 9 & 3 \\
Listeria-positive $(n=0)$ & 0 & 0 \\
Total Herring samples $(n=90)$ & 60 & 30 \\
\hline
\end{tabular}

Table (4) Antibacterial sensitivity test for pathogenic Salmonella strains isolated from Herring samples collected from souk and supermarkets Herring samples: R=Resistant to tested antibiotic.

\begin{tabular}{lllllllll}
\hline & Cefoze & Gentamic & Ciproci & Cefotaxi & Norfloxac & & E- & Doxycycli \\
Sampl & $\mathrm{n}$ & in & $\mathrm{n}$ & me & in & nexcla & \multicolumn{2}{c}{ indamyc } \\
e No. & $(\mathrm{CFP})$ & $(\mathrm{CN})$ & $(\mathrm{CIP})$ & $(\mathrm{CTX})$ & $(\mathrm{NOR})$ & & ve & (DA) \\
& & & & & & & (AMC) & \\
16 & 14 & 10 & 22 & 13 & 30 & 13 & $\mathrm{R}$ & $\mathrm{R}$ \\
17 & $\mathrm{R}$ & 18 & 10 & 21 & 30 & 11 & $\mathrm{R}$ & $\mathrm{R}$ \\
\hline
\end{tabular}

Table (5): Antibacterial sensitivity test for pathogenic E.coli strains isolated from Herring samples collected from souk and supermarkets Herring samples:

\begin{tabular}{lllllllll}
\hline $\begin{array}{l}\text { Sampl } \\
\text { e No }\end{array}$ & Cefozo & Gentamic & Ciproci & Cefotaxi & Norfloxac & & E- & Doxycycli \\
& $\mathrm{n}$ & in & $\mathrm{n}$ & me & in & Moxcla & $\begin{array}{l}\text { clindamyc } \\
\text { in }\end{array}$ \\
& $(\mathrm{CFP})$ & (CN) & (CIP) & (CTX) & $($ NOR) & & ve & (DA) \\
1 & $\mathrm{R}$ & 13 & 25 & $\mathrm{R}$ & 25 & $\mathrm{R}$ & $\mathrm{R}$ & $\mathrm{R}$ \\
28 & $\mathrm{R}$ & 11 & 27 & $\mathrm{R}$ & 23 & 20 & $\mathrm{R}$ & $\mathrm{R}$ \\
29 & $\mathrm{R}$ & 10 & 15 & $\mathrm{R}$ & 21 & 20 & $\mathrm{R}$ & $\mathrm{R}$ \\
33 & $\mathrm{R}$ & 20 & 24 & $\mathrm{R}$ & 15 & 11 & $\mathrm{R}$ & $\mathrm{R}$ \\
43 & 25 & 25 & 32 & 22 & 30 & 10 & $\mathrm{R}$ & $\mathrm{R}$ \\
$9 \mathrm{~m}$ & $\mathrm{R}$ & $\mathrm{R}$ & 22 & $\mathrm{R}$ & 12 & 12 & $\mathrm{R}$ & $\mathrm{R}$ \\
\hline
\end{tabular}

$\mathrm{R}=$ Resistant to tested antibiotic. 
Table (6): Oligonucleotide primers sequences

Source: Metabion (Germany).

\begin{tabular}{llll}
\hline Primer & Sequence & $\begin{array}{l}\text { Amplified } \\
\text { product }\end{array}$ & Reference \\
blaTEM & ATCAGCAATAAACCAGC & $516 \mathrm{bp}$ & Colom et al., \\
& CCCCGAAGAACGTTTTC & & 2003 \\
ermB & GAAAAAGTACTCAACCAAATA & $639 \mathrm{bp}$ & $\begin{array}{l}\text { Nguyen et } \\
\end{array}$ \\
& AATTTAAGTACCGTTACT & & al., 2009 \\
\hline
\end{tabular}

Table (7): Preparation of PCR Master Mix according to Emerald Amp GT PCR mastermix (Takara) Code No. RR310A.

\begin{tabular}{|c|c|}
\hline Component & Volume/reaction \\
\hline $\begin{array}{l}\text { Emerald Amp GT PCR mastermix ( } 2 x \\
\text { premix) }\end{array}$ & $12.5 \mu l$ \\
\hline PCR grade water & $4.5 \mu l$ \\
\hline Forward primer (20 pmol) & $1 \mu l$ \\
\hline Reverse primer $(20 \mathrm{pmol})$ & $1 \mu l$ \\
\hline Template DNA & $6 \mu l$ \\
\hline Total & $25 \mu l$ \\
\hline
\end{tabular}

Table (8): Cycling conditions of the different primers during cPCR

\begin{tabular}{lllllll}
\hline Gene & $\begin{array}{l}\text { Primary } \\
\text { denaturation }\end{array}$ & $\begin{array}{l}\text { Secondary } \\
\text { denaturation }\end{array}$ & Annealing & Extension & $\begin{array}{l}\text { No. of } \\
\text { cycles }\end{array}$ & $\begin{array}{l}\text { Final } \\
\text { extension }\end{array}$ \\
blaTEM & $94^{\circ} \mathrm{C}$ & $94^{\circ} \mathrm{C}$ & $54^{\circ} \mathrm{C}$ & $72^{\circ} \mathrm{C}$ & 35 & $72^{\circ} \mathrm{C}$ \\
& $5 \mathrm{~min}$. & $30 \mathrm{sec}$. & $40 \mathrm{sec}$. & $45 \mathrm{sec}$. & & $10 \mathrm{~min}$. \\
& & & & & \\
$\mathrm{ermB}$ & $94^{\circ} \mathrm{C}$ & $94^{\circ} \mathrm{C}$ & $45^{\circ} \mathrm{C}$ & $72^{\circ} \mathrm{C}$ & 35 & $72^{\circ} \mathrm{C}$ \\
& $5 \mathrm{~min}$. & $30 \mathrm{sec}$. & $40 \mathrm{sec}$. & $45 \mathrm{sec}$. & & $10 \mathrm{~min}$.
\end{tabular}




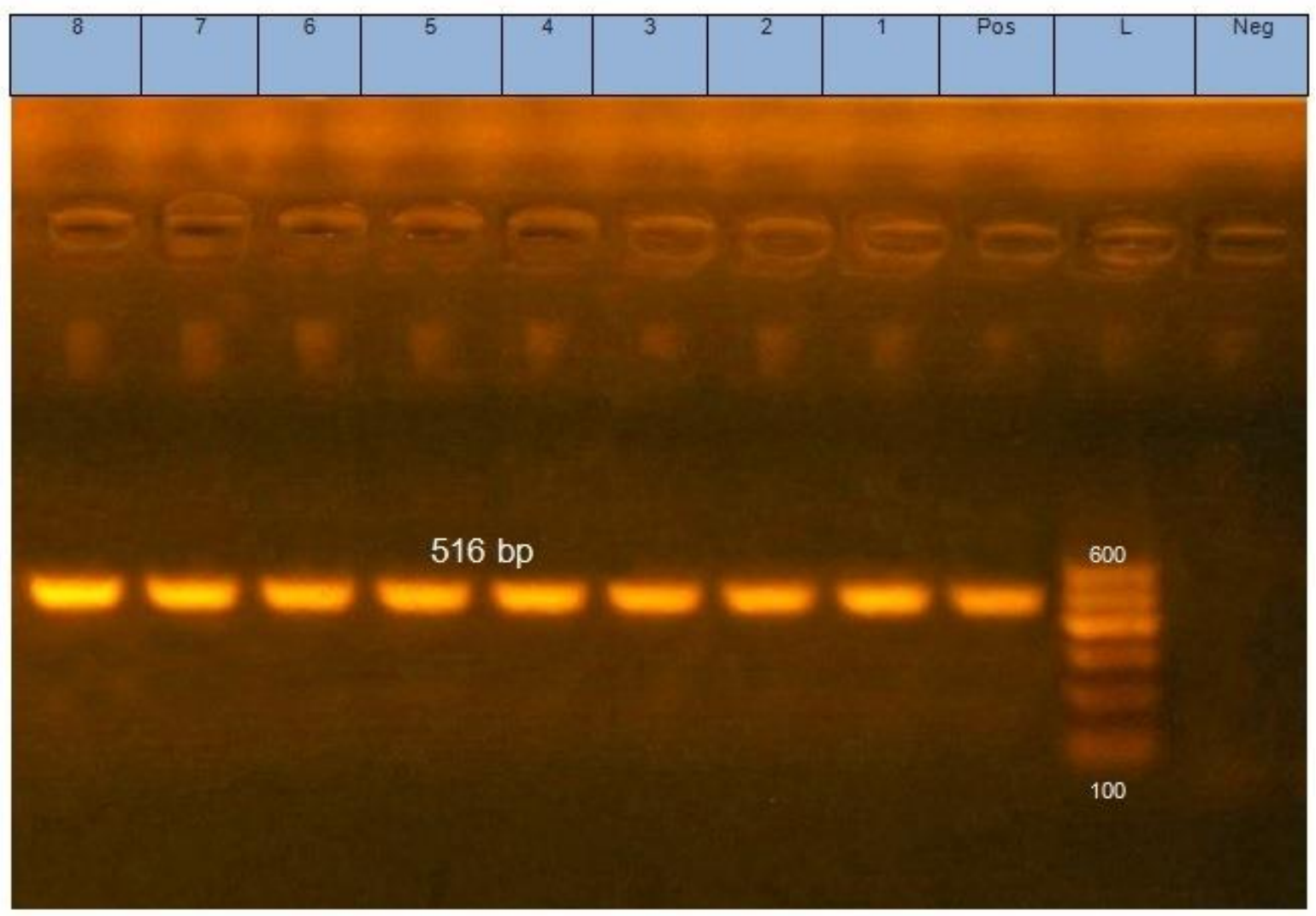

Figure (2) Results of PCR for detection of antibacterial resistance gene, blaTEM, in Salmonella and Escherichia coli strains isolated from Herring samples collected from Souk and supermarkets: bla ${ }_{\mathrm{TEM}}$, one of the most widespread antibiotic resistance genes in the environment, associated with Enterobacteriaceae.

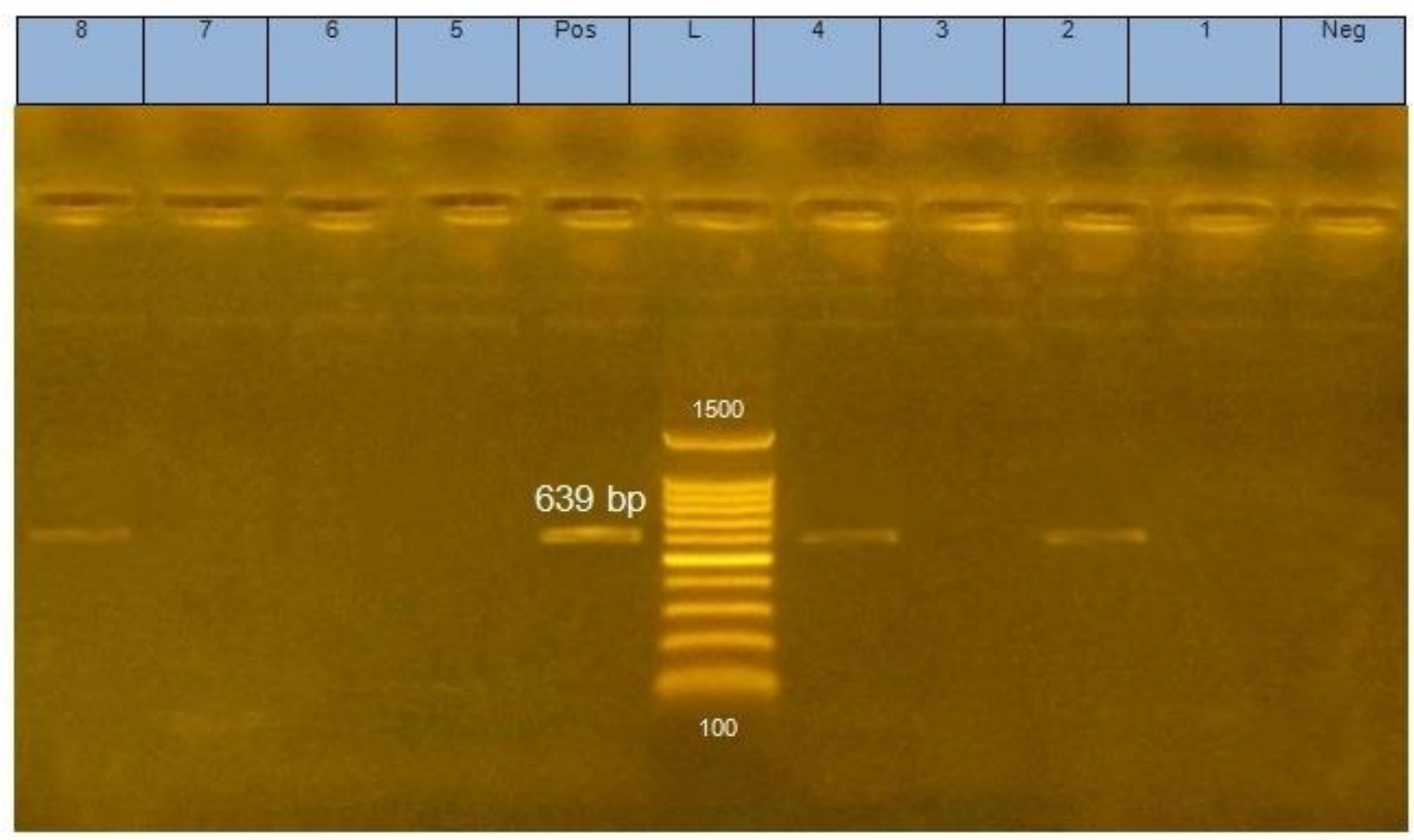

Figure (3) Results of PCR for detection of the erythromycin resistance gene, ermB, in Salmonella and Escherichia coli strains isolated from Herring samples collected from souk and super markets. 


\section{DISCUSSION}

At present, there is a large amount data on the microbiology and antimicrobial resistance of isolated pathogens from nonsmoked fish produced in Egypt. But the cold smoked Herring which is marketed in Egypt, no data about the antimicrobial resistance genes of isolated pathogens marketed.

Detection of Coliforms is used as a general indicator of sanitary condition and as means of measuring the effectiveness of decontamination programs in the foodprocessing environment and their presence indicating a substantially increased risk of the presence of pathogens (Lues and Van Tonder 2007; Moore and Griffith 2002).Here, the Coliform count of Souk cold smoked Herring and retail smoked Herring were counted and compared as shown in table $(1,2)$. The statistical analysis of results (Table 2) showed that the mean coliform count of a souk cold

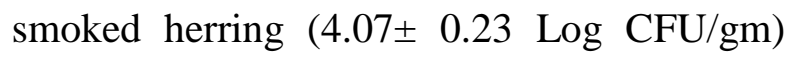
was significantly $(\mathrm{P}<0.05)$ higher than retail smoked Herring (3.13 \pm 0.40 Log CFU/gm). Of the 60 souk cold smoked Herrings, $13.3 \%$ $(8 / 60)$ samples were totally negative for the occurrence of Coliform, with a maximum Coliform count of $6.78 \mathrm{Log}$ CFU/gm. Besides, 30\% (9/30) of retail cold smoked Herrings were free of Coliform, with a maximum Coliform count of $6.68 \mathrm{Log}$ CFU/gm. Also, Dike-Ndudim et al. (2014) found that smoked fish distributed by Hawkers had higher mean coliform count (5.7 Log cfu/g) than in factory smoked fish (4.4 Log $\mathrm{cfu} / \mathrm{g}$ ), and greater than marketed smoked fish (4.6 Log cfu/g). Further, earlier study detected Coliform in $33 \%$ and $8.3 \%$ of cold smoked Cod and Salmon, at levels of $>100$ $\mathrm{CFU} / \mathrm{ml}$, but were not detected from hot smoked herrings (kippers) (Dillon et al. 1992). The current coliform counts were close to that obtained from smoked fish distributed by hawkers in Nigeria, where the range was 3.5to 5.3 Log CFU/gm (Akinwumi and Adegbehingbe 2015). The probable reasons for this significant coliform load on souk smoked fish, briefly is unhygienic distribution conditions of cold smoked herring, which involve the open exhibition of fish without any chilling storage, flies and insects which contact the offered herring in open boxes, and the personal hygiene is not priority for street vendor. Additionally, the variation in the results between a souk and retail smoked fish may be attributed to the differences in handling from producers to consumers and the effectiveness of hygienic measures applied during production, difference in manufacture practice and lack of hygienic measures applied during smoking process. Lacking personal hygiene amongst food handlers and poor hand and surface hygiene are of the most commonly reported practices contributing to food-borne illness (Cogan et al. 2002; Lues and Van Tonder 2007).The overall prevalence of Salmonella spp. currently isolated from cold smoked herring marketed in Egypt were 2.2\% (2/90). The two Salmonella spp. were only detected in smoked herring from souk samples, while no Salmonella spp. was detected in cold smoked herring sold in tested Egyptian retails (Tables 3). Current Salmonella rate is lower than the incidence rate $(6.67 \%)$ observed by Sifuna et al. (2008) in the fish products sold in Kenya. In Europe, prevalence of Salmonella in fish and fish products ranged between 0.3-8.5\%, and caused $1.4 \%$ of food-borne Outbreaks (EFSA (European Food Safety Authority) 2010). In China, the contamination rate of Salmonella in seafood samples was $20.8 \%$ (20/96) (Yan et al. 2010). Naturally, Salmonella is not a component of the normal flora of sea animals, thus contamination of seafood is mostly a result of fecal contamination which may happen through 
polluted water, infected food handlers or cross-contamination during production or transport (Lunestad and Borlaug 2009). Unmanaged condition of Egyptian souk, in contrast to retails condition, provide higher contamination opportunities with salmonella. In the past, the lack of washroom facilities and complete lack of refrigeration of the fish products, similar to the condition of Egyptian souk, were the major factors responsible for appearance of three Salmonella outbreaks due to consumption of contaminated smoked fish in the United States (Olitzky et al. 1956). Also, inadequate handling of smoked fish during processing may also lead to contamination with salmonella spp., as reported in 2012, smoked salmon contaminated with Salmonella Thompson accounted for the most extensive food-related outbreaks of Salmonella ever recorded in Netherlands, caused 1149 cases of salmonellosis (Suijkerbuijk et al. 2016). The overall prevalence of Escherichia coli in collected cold smoked herrings was $13.3 \%$. To illustrate, the incidence of Escherichia coli in the examined souk samples were $15 \%$ $(9 / 60)$, while the incidence in retail samples was $10 \%$ (3/30) (Tables 3). These results were lower than that recorded by Sifuna et al. (2008), where they found all the tested fish were contaminated with E. coli. Generally, Escherichia coli is indicator organisms associated with hygiene practices and their presence in food considered as indicator of faults during preparation, handling, storage, or service (Feng et al. 2002). Escherichia coli is readily killed by temperature above $55^{\circ} \mathrm{C}$, however the recent study carried out on cold smoked herring, which may facilitate the survival of Escherichia coli in originally contaminated fresh herrings before smoking process, because according to Kenneth and Hilderbrand (1992) cold smoking is a method where the temperature is maintained below $35^{\circ} \mathrm{C}$. Then, cooling down to less than $3.3{ }^{\circ} \mathrm{C}$ as quickly as possible and keeping products at that temperature to reduce the growth of food poisoning bacteria until consumption. Also, inadequate handling of fish in thermally uncontrollable environment may explain the higher rate of Escherichia coli in souk samples than those collected from thermally controllable retails. A wide range of raw materials for fish products production can potentially contain L. monocytogenes (Porsby et al. 2008). Ready -to-eat (RTE) foods, such as smoked fish, and seafood are high risk foods for Listeria sp. that their consumption was responsible for more than $99 \%$ of human listeriosis (Allen et al. 2016; Swaminathan and Gerner-Smidt 2007; Tham et al. 2000). The last described severe outbreaks were in Denmark, comprising eight deaths, and related to cold smoked fish (Lassen et al. 2016), while earlier outbreaks of listeriosis associated with the consumption of coldsmoked rainbow trout were reported in Sweden, consisting of nine cases (Ericsson et al. 1997), and Finland, comprised 5 persons (Miettinen et al. 1999).Currently, all examined cold smoked herrings from souk and retail were negative for the presence of Listeria sp. These result was in concordance with many previous studies, where it was totally absent in vacuum-packed cold-smoked salmon and trout (Gonzalez-Rodriguez et al. 2002). Fortunately, Listeria sp. prevalence is low; range from $0-1 \%$ or $1-10 \%$ (Løvdal 2015). In contrast, Soultos et al. (2007) found that the overall incidence of Listeria spp. in the fish samples were $4 \%$, while Fuchs and Nicolaides (1994) isolated Listeria spp. and Listeria monocytogenes from $8.6 \%(5 / 58)$ and $3.4 \%(2 / 58)$ of the cold-smoked fish. Higher prevalence rate was reported in smoked seafood by Dillon et al. (1992), was $11.3 \%$. Concerning the sources of listeria sp., it is enough to know that L. monocytogenes has ability to persist for months or even years in fish production environments which may be 
involved in its transmission from contaminated surfaces to food products (Lassen et al. 2016; Overney et al. 2017). Because L.monocytogenes has the ability to survive and grow cold smoking, together with their high morbidity and mortality rate (2040\%) makes governments, as the U.S. and Denmark adopted a zero tolerance criteria for L. monocytogenes in RTE products (Løvdal 2015).Commercial fish and seafood may act as the reservoir for multi-resistant bacteria and facilitate the dissemination of the resistance genes. Antibiotic susceptibility tests conducted on bacterial isolates from smoked fish, showed that multi drugresistance, defined as resistance to at least 3 different classes of antibiotics (Van et al. 2008), was detected in one Salmonella strains. In detail, the two isolated Salmonella strains (100\%) showed resistance to E-Moxclave, and clindamycin, while one Salmonella strains additionally showed resistance to Cefozon (50\%). In contrast both strains were susceptible to Gentamicin (100\%), Ciprocin (100\%), Cefotaxime (100\%), Norfloxacin $(100 \%)$, Doxycycline (100\%). Similarly, Yan et al. (2010) reported that all 20 Salmonella strains isolated from seafood were susceptible Norfloxacin, but none of the strains were resistant to Amoxicillin-clavulanate (as EMoxclave) and Cefozon, while 5\%, 5\% and $10 \%$ were resistant to Gentamicin to Ciprofloxacin (Ciprocin) and Tetracycline (Doxycycline), respectively. All isolated E. coli strains were resistant to one or more antibiotics. The multi-resistance was observed in $83.3 \%(5 / 6)$ of tested E. coli strains. Of them, two isolates were resistant to 5 tested antibiotics and the other $2 \mathrm{E}$. coli strain were resistant to 4 tested antibiotics. Further, 100\% of isolated E. coli strain were resistant EMoxclave, and clindamycin, while $83.3 \%$ (5/6) showed resistance to Cefozon and Cefotaxime. Also, 16.7\% (1/6) of E. coli were resistant to Gentamicin (Aminoglycosides) and to Doxycycline. However, all isolated E. coli $(100 \%)$ were susceptible to Norfloxacin. In contrast to current results Ryu et al. (2012) observed no resistances to amoxicillin/clavulanic acid and cefoxitin by the isolated E. coli from Fish and seafood in Korea. In the current study, the result showed that all isolated salmonella $(\mathrm{n}=2)$ and E. coli $(n=6)$ strains contained the beta-lactam resistance genes, blaTEM detected in the 8 isolates (100\%). Ryu et al. (2012) detected beta-lactam resistance gene, blaTEM gene in 15 ampicillins resistant $(\mathrm{n}=12)$ and susceptible $(n=3)$ isolates of $E$. coli. Azithromycin showed better outcomes than ceftriaxone in treating people suffering of uncomplicated forms of Enteric fever (typhoid and paratyphoid fever) (Effa and Bukirwa 2008). On the other hand, one of two salmonella isolates and two of six E. coli strains were positive for erm(B) (erythromycin ribosome methylase) genes. This gene is among many which confer full cross-resistance between erythromycin and azithromycin (Leclercq 2002). Methylation of ribosomal target to impair antibiotic attachment, remains the most widespread mechanism of resistance to macrolides. Former study found that E. coli might constitute a major reservoir for macrolide resistance genes, where the erm(B) gene was detected in 6 isolates of $\mathrm{E}$. coli from 2 continents, Asia (5/37) and Europe (1/100) (Nguyen et al. 2009). Isolated pathogens showed variable phenotypic degree of resistance included Aminoglycosides, fluoroquinolones, cephalosporins, and macrolides, a four classes of antimicrobials which were categorized among the critically important antimicrobials for treating human's salmonellosis ( typhoid and paratyphoid fever as well as severe non typhoidal infections) (CDC (Centers for Disease Control Prevention) 2016; WHO (World Health Organization) 2007).Current results concur 
with former studies concluded that TEM-type $\beta$-lactamases were the most prevalent in $\mathrm{E}$. coli isolates from seafood (Ryu et al. 2012). Also, Van et al. (2008) detected betalactamase blaTEM gene in $84.2 \%$ of the tested E. coli isolates from shell fish and food of animal origin. Acquired antimicrobial resistance in human L. monocytogenes isolates is rare (Hansen et al. 2005), though a significant frequency of acquired antimicrobial resistance has been detected in animal isolates (Srinivasan et al. 2005). Surprisingly, this may be a precursor for emergence of antimicrobial resistance in clinical human isolates (Swaminathan and Gerner-Smidt 2007). Cold smoked fish marketed in Egypt, particularly in souk can be a source of multi-antibiotic resistant Salmonella and E. coli strains for consumers. Thus, there is a paramount need to implement measures for hygienic storage and distribution of smoked fish, in addition to the examination of imported ready smoked or raw herrings for antimicrobials to prevent further increase in the occurrence of antimicrobial resistance in Egypt. In assuring the safety of seafood, continuous screening for antimicrobial resistant bacteria from smoked fish and seafood is needed.

\section{REFERENCES}

Akinwumi, F.O. \& Adegbehingbe, K.T. (2015) Microbiological Analysis of Three of Smoked Fish Obtained from the Ondo State, Nigeria Food and Public Health, 5:125-129.

Allen; Wałecka-Zacharska; Chen; Katarzyna; Devlieghere; Van Meervenne; Osek; Wieczorek and Bania (2016): Listeria Monocytogenes-an Examination of Food Chain Factors Potentially Contributing to Antimicrobial Resistance. Food Microbiol., 54: 178-189.
Anderson, J. B.; Shuster, T.A.; Hansen, K.E.; Levy, A.S.\& Volk, A. (2004) A camera's view of consumer food-handling behaviors Journal of the american dieteticassociation,104:186-191.

Borch, E. \& Arinder, P. (2002) Bacteriological safety issues in red meat andready-to-eat meat products, as well as control measures Meat science, 62:381-390.

CDC (Centers for Disease Control Prevention) (2016) National Antimicrobial Resistance Monitoring System for Enteric Bacteria (NARMS): Human Isolates Surveillance Report for 2014 (Final Report) Atlanta, Georgia, USA: US.

CDC. (Centers for Disease Control and Prevention) (2017) Surveillance for Foodborne Disease Outbreaks, United States, 2015, Annual Report. Atlanta,Georgia: US Department of Health and Human Services.

Cogan, T.; Slader, J.; Bloomfield, S. \& Humphrey, T. (2002) Achieving hygiene in the domestic kitchen: the effectiveness of commonly used cleaning procedures Journal of Applied Microbiology, 92:885892.

Colom, K.; Pérez, J.; Alonso, R.; FernándezAranguiz, A.; Lariño, E. \& Cisterna R (2003) Simple and reliable multiplex PCR assay for detection of bla TEM, bla SHV and bla OXA-1 genes in Enterobacteriaceae FEMS microbiology letters, 223:147-151.

De Noordhout, C.M. (2014) The global burden of listeriosis: a systematic review and metaanalysis The Lancet Infectious Diseases, 14:1073-1082.

Dike-Ndudim.; Egbuobi.; Onyeneke.; Uduji.; Nwagbaraocha.; Ogamaka.; Okorie.; Egbuobi. \& Opara. (2014): Microbial 
status of smoked fish, scombia scombia soldinOwerri,Imostate,NigeriaAfricanJour nalofClinicalandExperimentalMicrobiolog $\mathrm{y}, 15: 35-39$.

Dillon R, Patel, T. \& Ratnam, S. (1992) Prevalence of Listeria in smoked fish Journal of Food Protection, 55:866-870.

Donovan, S. (2015) Listeriosis: a rare but deadly disease Clinical Microbiology Newsletter, 37:135-140.

Effa, E.E. \& Bukirwa, H. (2008) Azithromycin for treating uncomplicated typhoid and paratyphoid fever (enteric fever) The Cochrane database of systematic reviews:Cd006083.

-EFSA (European Food Safety Authority) (2010) The Community Summary Report: Trends and Sources of Zoonoses and Zoonotic Agents and Food-borne Outbreaks in the European Union in 2008. European food safety authority.

Ericsson, H.; Eklöw; Danielsson-Tham; Loncarevic; Mentzing; Persson; Unnerstad \& Tham (1997) An outbreak of listeriosis suspected to have been caused by rainbow trout Journal of Clinical Microbiology,35:2904-2907.

ES (2006) ES No. 5105-2006: (ISO: 11290-1/ 1996) microbiology of food and animal feeding stuffs - horizontal method for the detection of listeria monocytogenes Egypt Organization for Standards \& Quality.

Edwards \&Ewing's, W.H. (1986) Identification of Enterobacteriaceae. 4th edition. Elsevier

SciencePublishingCo.Inc.,NewYork.

FAO (2016) the State of World Fisheries and Aquaculture. Contributing to Food Security and Nutrition for All
Feng, P.; Weagant, S.D.; Grant, M.A.; Burkhardt, W.; Shellfish, M. \& Water, B. (2002): Enumeration of Escherichia coli and the Coliform Bacteria Bacteriological analytical manual, 13-19.

Firestone, S.; Bell, C.; Sault, C.; Stephens, N. \& Lightfoot, D. (2007) Large outbreaks of Salmonella Typhimurium phage type 135 infections associated with the consumption of products containing raw egg in Tasmania Communicable diseases intelligence quarterly report,31:118.

Fuchs, R.S. \& Nicolaides, L. (1994) Incidence of Listeria in hot- and cold-smoked fish Letters in applied microbiology,19:394396.

Gnanou Besse, N.; Favret, S.; Desreumaux, J.; Decourseulles Brasseur, E. \& Kalmokoff, M. (2016) Evaluation of reduction of Fraser incubation by $24 \mathrm{~h}$ in the EN ISO 11290-1 standard on detection and diversity of Listeria species Int J Food Microbiol,224:16-21.

Gonzalez-Rodriguez, M.N.; Sanz, J.J.; Santos, J.A.; Otero, A. \& Garcia-Lopez, M.L. (2002) Numbers and types of microorganisms in vacuum-packed cold-smoked freshwaterfishattheretaillevelInt.J.FoodMicrobiol, 77:161-168.

Grimont, P.A. \& Weill, F.X. (2007) Antigenic formulae of the Salmonella serovars WHO collaborating center for reference and research on Salmonella 9:1-166.

Hansen, J.M.; Gerner-Smidt, P. \& Bruun, B. (2005) Antibiotic susceptibility of Listeria monocytogenes in Denmark 1958-2001 Apmis, 113:31-36.

ISO (International Organization for Standardization) (2002): Laboratory Protocol "Isolation of Salmonella spp. from Food and Animal Faces" 
ISO (International Organization for Standardization) (2005) Microbiology of food and animal feeding stuffs-horizontal method for the enumeration ColiformsColony-Count thchnique. Isolation of Salmonella spp From Food and Animal Faeces.

ISO (International Organization for Standardization) (2014) ISO/TR 65793:2014(en) Microbiology of the food chain - Horizontal method for the detection, enumeration and serotyping of Salmonella - Part 3: Guidelines for serotyping of Salmonella spp. International Organization for Standardization, Geneva, Switzerland.

Kenneth, S. \& Hilderbrand, J. (1992) Fish smoking procedures for forced convection smokehouses. Oregon: Oregon State University Extension Service.

Lassen, S.G.; Ethelberg; Björkman; Jensen; Sørensen; Jensen; Müller; Nielsen and Mølbak (2016) Two Listeria outbreaks caused by smoked fish consumptionusing whole-genome sequencing for outbreak investigations Clinical Microbiology and Infection, 22:620-624.

Leclercq, R. (2002) Mechanisms of Resistance to Macrolides and Lincosamides: Nature of the Resistance Elements and Their Clinical Implications Clinical InfectiousDiseases, 34:482-492.

Løvdal, T. (2015) The microbiology of cold smoked salmon Food Control, 54:360373.

Lues, J. F. R. \& Van Tonder, I. (2007) The occurrence of indicator bacteria on hands and aprons of food handlers in the delicatessen sections of a retail group Food Control,18:326-332.
Mabilat, C. \& Courvalin, P. (1990) Development of "oligotyping" for characterization and molecular epidemiology of TEM betalactamases in membersofthefamily EnterobacteriaceaeAntimicrobAgentsChe mother,34:2210-2216.

Miettinen, M.K.; Siitonen, A.; Heiskanen, P.; Haajanen, H.; Bjorkroth, K.J. \& Korkeala, H.J. (1999) Molecular epidemiology of an outbreak of febrile gastroenteritis caused by Listeria monocytogenes in coldsmoked rainbow trout J.Clin.Microbiol.,37:2358-2360.

Moore, G. \& Griffith, C. (2002) Acomparison of surface sampling methods for detecting coliforms on food contact surfaces Food microbiology, 19:65-73.

Møretrø, T.; Schirmer, B. C.; Heir, E. Fagerlund, A.; Hjemli, P. \& Langsrud, S. (2017) Tolerance to quaternary ammonium compound disinfectants may enhance growth of Listeria monocytogenes in the food industry International journal of foodmicrobiology,241:215-224.

Nguyen, M.C.P.; Woerther, P.L.; Bouvet, M.; Andremont, A.; Leclercq, R. \& Canu, A. (2009) Escherichia coli as Reservoir for Macrolide Resistance Genes Emerging InfectiousDiseases, 15:1648-1650.

-Olitzky, I.; Perri, A.; Shiffman, M. \& Werrin, M. (1956) Smoked fish as a vehicle of salmonellosisPublicHealthReports, 71:773.

Overney, A.; Jacques-André-Coquin, J. Ng. P.; Carpentier, B.; Guillier, L. \& Firmesse, O. (2017) Impact of environmental factors on the culturability and viability of Listeria monocytogenes under conditions encountered in food processing plants Internationaljournaloffoodmicrobiology, 2 44:74-81. 
Porsby, C.H.; Vogel, B.F.; Mohr, M. \& Gram, L. (2008) Influence of processing steps in cold-smoked salmon production on survival and growth of persistent and presumed non-persistent Listeria monocytogenes International journal of food microbiology, 122:287-295.

Ryu, S.H. (2012) Antimicrobial resistance and resistance genes in Escherichia coli strains isolated from commercial fish and seafood International Journal of Food Microbiology,152:14-18.

Scotter, S.L. (2001) Validation of ISO method 11290 Part 1 - Detection of Listeria monocytogenes in foods International Journal of Food Microbiology, 64:295306.

Sifuna, A.W.; Njagi, E.N.; Okemo, P.; Munyalo, A. Orinda, G.O. \& Kariuki, S. (2008) Microbiological quality and safety of Rastrineobola argentea retailed in Kisumu town markets, Kenya East African medical journal,85:509-513.

Soultos N, Abrahim A, Papageorgiou K, Steris V (2007) Incidence of Listeria spp.in fish and environment of fish markets in Northern Greece Food Control, 18:554557.

Srinivasan, V.; Nam, H.M.; Nguyen, L.T. Tamilselvam, B. Murinda, S.E. \& Oliver, S.P. (2005) Prevalence of antimicrobial resistance genes in Listeria monocytogenes isolated from dairy farms Foodborne Pathog Dis., 2:201-211.

Suijkerbuijk, A.W.; Bouwknegt, M.; Mangen, M.J.J.; de Wit, G.A.; van Pelt, W.; Bijkerk, P. \& Friesema, I.H. (2016) The economic burden of a Salmonella Thompson outbreak caused by smoked salmon in the Netherlands, 2012-2013
TheEuropeanJournalofPublicHealth,27:32 5-330.

Sutton, S. (2011) Accuracy of plate counts Journal of validation technology 17:42.

Swaminathan B, Gerner-Smidt P (2007) The epidemiology of human listeriosis Microbes and infection, 9:1236-1243.

Tham, W.; Ericsson, H.; Loncarevic, S.; Unnerstad, H. \& Danielsson-Tham, M.L. (2000) Lessons from an outbreak of listeriosis related to vacuum-packed gravad and cold-smoked fish International Journal of Food Microbiology, 62:173175 .

Van, T.T.; Chin, J.; Chapman, T.; Tran, L.T. \& Coloe, P.J. (2008) Safety of raw meat and shellfish in Vietnam: an analysis of Escherichia coli isolations for antibiotic resistance and virulence genes Int. J. Food Microbiol., 124:217-223.

WHO (World Health Organization) (2007) Critically important antimicrobials for human medicine: categorization for the development of risk management strategies to contain antimicrobial resistance due to non-human antimicrobial use: report of the second WHO Expert Meeting, Copenhagen, 29-31.

Yan, H. Li. L.; Alam, M.J.; Shinoda, S.; Miyoshi, S. i. \& Shi, L. (2010) Prevalence and antimicrobial resistance of Salmonella in retail foods in northern China International journal of food microbiology, 143:230-234. 